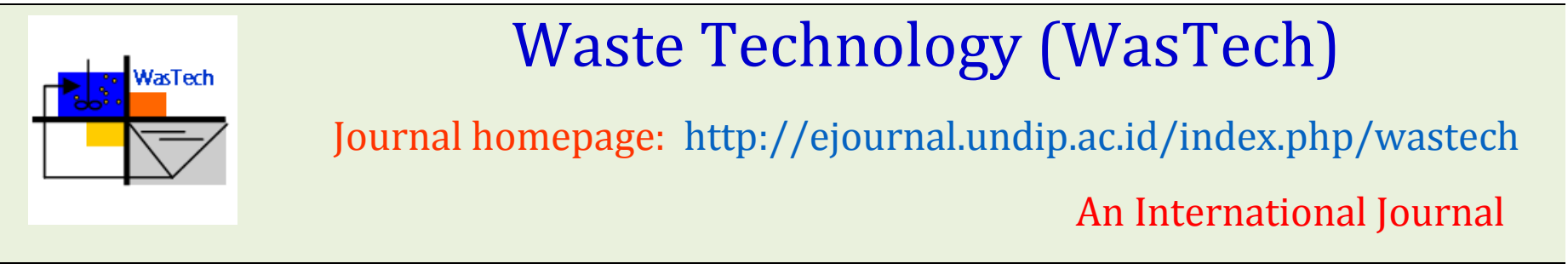

\title{
Accumulation Level and Pollution State of Zinc (Zn) Within Mangrove Forest Sediment and Water Of Demak Coastal Region
}

\author{
Endah Dwi Hastuti \\ Laboratory of Biology Structure and Function of Plant, Faculty of Science and Mathematics Diponegoro University \\ Jl. Prof. Soedarto SH, Tembalang, Semarang, Indonesia 50275 \\ Email: endah_pdil@yahoo.com
}

\begin{abstract}
Abstrac - Zinc (Zn) is essential heavy metal for plant growth, but could be lethal for some aquatic organisms. While its accumulation in mangrove ecosystem increased along with the increasing input to the river runoff. This research aimed to observe the concentration of Zn in mangrove sediment and water within mangrove ecosystem in Demak coastal area and its pollution state. This research was conducted through observation involving 4 sampling stations and 3 sampling transects at each station. Data collection including mangrove structure and concentration of Zn in mangrove sediment and water. The result showed that mangrove distribution along Demak coastal area varied among stations. Station 1 and station 2 consist of Avicennia marina only, while station 3 consist of Avicennia marina and Rhizophora mucronata and station 4 consist of Avicennia marina, Rhizophora mucronata and Rhizophora stylosa. Average sediment heavy metal concentration at each station was: $415.81 \mathrm{mg} / \mathrm{kg} ; 561.15 \mathrm{mg} / \mathrm{kg} ; 486.23 \mathrm{mg} / \mathrm{kg}$ and 11,507.18 mg/kg respectively. While average heavy metal concentration in mangrove water was $0.12 \mathrm{mg} / \mathrm{l} ; 0.12 \mathrm{mg} / \mathrm{l} ; 0.09 \mathrm{mg} / \mathrm{l}$ and $0.17 \mathrm{mg} / \mathrm{l}$ respectively. The concentration of heavy metal in mangrove water of Demak region had exceed the maximum limit allowed by the government; while the sediment concentration of heavy metal had exceed tha suitable concentration for organisms.
\end{abstract}

Keywords-Mangrove, Demak, Zn, sediment, water

Submission: September 2, $2014 \quad$ Correction: October 2, 2014

Accepted: October 12, 2014

Doi: http://dx.doi.org/10.12777/wastech.2.2.52-55

[How to cite this article: Hastuti, E.D.. (2014). Accumulation Level and Pollution State of Zinc (Zn) within Mangrove Forest Sediment and Water of Demak Coastal Region, Waste Technology, 2(2):41-43. Doi: http://dx.doi.org/10.12777/wastech.2.2.52-55]

\section{INTRODUCTION}

Mangrove ecosystem had been known to provide natural function to protect coastal area from the impact of the ocean and land activities. According to Yunus et al. (2011) mangrove sediments have the capability to trap and retain heavy metals from indirectly enters the other ecosystem, such as seagrass and coral ecosystem. Mangrove trees has strong capabilities in heany metals absorption and fixation (Kumar et al., 2010). According to Defew et al. (2005), the capability of mangrove ecosystem in heavy metal retention is caused by its anaerobic and reduced condition which is rich of sulphide and organic matter.

Coastal ecosystem in tropical countries are mostly mangrove abundant. Demak region is one of many regions in Central Java which naturally abundant of mangrove plants. Mangrove ecosystems are mostly found around the estuaries and immersed wetlands. Unfortunately, increasing upland activities lead to the increase of pollutant discharge to aquatic system, such as river runoffs, estuaries and coasts. According to Kathiresan (2003), complexity of mangrove aerial roots play an important rules in sediment trapping. In the other side, Nasr et al. (2006) mentioned that sediment serve as heavy metal reservoir. There were also correlation between sediment grain size and heavy metal concentration. Finer sediment grain size contain more heavy metal concentration than coarse sediment (Maslennikova et al., 2012).

Since mangrove plays important rule in sediment trapping, heavy metal accumulation comes along with sedimentation process. Concentrations of heavy metal in mangrove sediments all over the world are elevated which are caused by long term pollution caused by human activities (Harris and Santos, 2000). According to Chaiyara et al. (2013), heavy metals are taken up directly grom discharges of coastal communities, ships, rivers, atmospheric deposition and land runoffs. Since urban development areas are close to mangrove ecosystem, large input of heavy metal into mangrove ecosystem are generated from industrial and domestic wastes 
which contain trace and heavy metal in dissolved particulate form (Preda and Cox, 2002).

Mangrove plants were also known to absorb and accumulate heavy metal in its tissues (Prica et al., 2007). According to Kumar et al. (2008), the uptake of heavy metal by plants is passive and its translocation from roots to other organs is generally low. The concentration of heavy metal within mangrove plants are varied among organs. Some heavy metals such as $\mathrm{Pb}$ and $\mathrm{Zn}$ are mostly acumulated in mangrove roots, while accumulation in stems and leaves are lower (Kumar et al., 2010).

Heavy metals are bioaccumulative especially to aquatic organisms. Some of them are essential to the life processes of organisms, while some other are toxic, even at low concentration (Jakimska et al., 2011). Heavy metal concentration and accumulation increases as the increase of throphic levels of the organisms. As the rise of heavy metal concentration within organisms, the risk of toxicity would rise eiter. Excessive concentration of heavy metals have varied toxic effects on living organisms via metabolic interverence and mutagenesis (Govind and Madhuri, 2014).

Zinc $(\mathrm{Zn})$ is one kind of heavy metal regarded as serius pollutant in aquatic ecosystem because of its environmental persistence, toxicity and ability to be incorporated into food chains (Kishe and Machiwa, 2003). According to Chaiyara et al. (2013) Zn plays an important role in cellular metabolism and can be regulated by organisms in their body. A research conducted by Kumar et al. (208) showed that mangrove sediments could contain $8.1 \mathrm{mg} / \mathrm{kg}$ of $\mathrm{Zn}$ while mangrove water could contain $3.89 \mathrm{mg} / \mathrm{L}$ of $\mathrm{Zn}$. While the observation on mangrove organs revealed that $\mathrm{Zn}$ concentration in mangrove leaves, stems and roots were $2.89 \mathrm{mg} / \mathrm{kg}, 1.49$ $\mathrm{mg} / \mathrm{kg}$ and $4.0 \mathrm{mg} / \mathrm{kg}$ respectively.

Several research had been conducted to observe the concentration of heavy metal on aquatic organisms, especially which lived within the mangrove ecosystem. A research conducted by Chaiyara et al. (2013) detected $\mathrm{Zn}$ concentration within mangrove crabs ranged from $0.38-3.92 \mathrm{mg} / \mathrm{kg}$. While Kamaruzzaman et al. (2010) observed the concentration of $\mathrm{Zn}$ in fish was $19.27 \mathrm{mg} / \mathrm{kg}$. Another research conducted by Hobbelen et al. (2006) showed the concentration of $\mathrm{Zn}$ in earthworms Lumbricus rubellus and Aporrectodea caliginosa ranged from $954-1,871 \mathrm{mg} / \mathrm{kg}$ dry weight and $676-1,958$ $\mathrm{mg} / \mathrm{kg}$ dry weight respectively.

Massive upland development had became the main problem to coastal ecosystem. Marine pollution such as heavy metal accumulation increased over time, and $\mathrm{Zn}$ is one of several heavy metal discharge which is resulted from the increasing anthropogenic activities. The accumulation of heavy metal in the mangrove ecosystem had became threats to coastal aquatic organisms. Hence, information concerning the current condition is required to formulate better management strategies. This research aimed to observe current concentration of $\mathrm{Zn}$ in sediment and water within mangrove ecosystem in Demak coastal area and its pollution state.

\section{MATERIALS AND METHOD}

This research was conducted through field observation and literature study. Observation was conducted in mangrove ecosystem within coastal area of Demak region. Four sampling station was occupied for observation, including 3 sampling transects at each station. Sampling stations were defined purposively to achieve proper information of heavy metal concentration from different mangrove structure. Total of 12 sampling transects was occupied to gain appropriate information concerning the distribution of Zinc ( $\mathrm{Zn}$ ) along the mangrove ecosystem in Demak coastal area. Each transect has $10 \times 10 \mathrm{~m} 2$ of sampling area.

To describe the condition of mangrove ecosystem in Demak coastal area, observation of mangrove structure was conducted. Observation including mangrove specieses, species abundance and species coverage of mangrove tree. Data analysis was including mangrove community structure such as relative abundance, relative dominance and index of importance was conducted. Analysis formula including:

$$
\mathrm{RA}: \frac{\mathrm{ni}}{\mathrm{N}} \quad \mathrm{X} 100 \%
$$

Notation:

$$
\begin{aligned}
& \mathrm{RA}=\text { Relative Abundance } \\
& \mathrm{ni}=\text { Abundance of Species i }
\end{aligned}
$$

$\mathrm{N}=$ Total Abundance

$\mathrm{RD}: \frac{\mathrm{BAi}}{\mathrm{BA}} \times 100 \%$

Notation:

$\mathrm{RA}=$ Relative Dominance
$\mathrm{BAi}=$ Basal Area of Species $\mathrm{i}$
$\mathrm{BA}=$ Total Basal Area

$$
\text { Importance Value Index: } \quad \mathrm{RA}+\mathrm{RD}
$$

Data of $\mathrm{Zn}$ concentration in mangrove ecosystem was observed from mangrove sediment and water. Samples of sediments were collected randomly from each transect with core sampler. The sediment was taken from the soil surface untill the depth of $30 \mathrm{~cm}$. While samples of water were colected from the floods within mangrove ecosystem. The analysis of sediment end water $\mathrm{Zn}$ concentration was conducted at Laboratory of Chemical Analythic, Diponegoro University Semarang. 


\section{RESULT AND DISCUSSION}

The observation on the mangrove structure showed there were 3 mangrove specieses found in coastal area of Demak region. Mangrove specieses including Avicennia marina, Rhizophora mucronata and Rhizophora stylosa. Species distribution and abundance were varied among stations. Avicennia marina was found at all sampling stations, where in sampling station 1 and 2 Avicennia marina was the only mangrove species found. The abundance of Avicennia marina was highest in sampling station 1 , and decrease at sampling station 2, 3 and lowest at sampling station 4 . The abundance of Avicennia marina was 4,067 - 5,600 trees/ha at station 1; $3,033-3,900$ trees/ha at station $2 ; 2,033-3,200$ trees/ha at station 3; and $0-400$ trees/ha at station 4 .

Rhizophora mucronata was found in sampling station 3 and 4 and most abundant in sampling station 4 . The abundance of Rhizophora mucronata at station 3 was 1,800 2,300 trees/ha and 4,100 - 5,200 trees/ha at station 4 . While Rhizophora stylosa was only found in sampling station 4 in low abundance, covering 67 trees/ha. Highest total average abundance was found at station 1 (4,700 trees/ha), followed by station 4 (4,678 trees/ha), station 3 (4,489 trees/ha) and station 2 (3,356 trees/ha). Avicennia marina was also observed as the most abundant mangrove species along coastal area of Demak, followed by Rhizophora mucronata and Rhizophora stylosa.

Analysis on the Importance Value Index of mangrove species resulted an absolute importance of Avicennia marina for sampling station 1 and 2, Since Avicennia marina was the only mangrove vegetation found in both station. At sampling station 3, Avicennia marina had higher Importance Value Index than Rhizophora mucronata. Importance Value Index of Avicennia at sampling station 3 was $127.81 \%$ including Relative Abundance of $55.94 \%$ and Relative Dominance of $71.87 \%$, while Rhizophora mucronata had the Importance Value Index of $72.19 \%$ including Relative Abundance of $44.06 \%$ and Relative Dominance of $28.13 \%$. Exceptional for sampling station 4, Rhizophora mucronata had the highest Importance Value Index followed by Avicennia marina and Rhizophora stylosa. Importance Value Index of Rhizophora mucronata was $174.04 \%$ including Relative Abundance of $76.36 \%$ and Relative Dominance of $97.68 \%$. The Importance Value Index of Avicennia marina was $22.05 \%$ including Relative Abundance of $20.26 \%$ and Relative Dominance of $1.79 \%$. While the Importance Value Index of Rhizophora stylosa was 3.91\% including Relative Abundance of 3.38\% and Relative Dominance $0.53 \%$.

Analysis on the $\mathrm{Zn}$ concentration within mangrove ecosystem in Demak coastal area showed its variation both in the sediment and in the water. Concentration of $\mathrm{Zn}$ in the sediment at sampling station 1 was lowest among other stations and station 3 has the lowest water $\mathrm{Zn}$ concentration, while at sampling station 4 was highest among other stations both for sediment and water. $\mathrm{Zn}$ concentration at station 1 was
$293.67-536.86 \mathrm{mg} / \mathrm{kg}$ in the sediment and $0.09-0.16 \mathrm{mg} / \mathrm{l}$ in the water. At station $2, \mathrm{Zn}$ concentration was 520.18 $599.95 \mathrm{mg} / \mathrm{kg}$ in the sediment and $0.10-0.14 \mathrm{mg} / \mathrm{l}$ in the water. At station 3, $\mathrm{Zn}$ concentration was $403.44-582.67$ $\mathrm{mg} / \mathrm{kg}$ in the sediment and $0.06-0.14 \mathrm{mg} / \mathrm{l}$ in the water. While at station $4, \mathrm{Zn}$ concentration was $11,108.04$ $12,101.44 \mathrm{mg} / \mathrm{kg}$ in the sediment and $0.07-0.17 \mathrm{mg} / \mathrm{l}$ in the water.

The concentration of $\mathrm{Zn}$ in mangrove water according to regulation of Indonesian Ministry of Environment had exceeded the allowable limit, but acording to USEPA (1986) the concentration were still under the permissible limit. According to Indonesian Ministry of Environement regulation No: 51 / 2004, concentration limit of $\mathrm{Zn}$ in the water is 0.05 $\mathrm{mg} / \mathrm{l}$ (Wahyuni et al., 2013), while according to USEPA (1986), concentration limit of $\mathrm{Zn}$ in the water is $1.00 \mathrm{mg} / \mathrm{l}$ (Saeed and Shaker, 2008). Concentration of $\mathrm{Zn}$ in mangrove sediments varied among regulations. According to CCME maximum concentration of $\mathrm{Zn}$ in sediment is $124 \mathrm{mg} / \mathrm{kg}$ (Saeed and Shaker, 2008), while ANZECC/ARMCANZ recommend the concentration range of $200-410 \mathrm{mg} / \mathrm{kg}$ (Lestari and Budiyanto, 2013), while IADC/CEDA recommend maximum concentration of $150 \mathrm{mg} / \mathrm{kg}$ (Wahyuni et al., 2013). According to the regulation mentioned, the contamination of $\mathrm{Zn}$ in mangrove sediment had exceed the allowable limit.

The observation of $\mathrm{Zn}$ concentration in mangrove ecosystem showed high accumulation rate in mangrove sediment, but not in mangrove water. It is because solubility of heavy metal in water is lower than its capability to attach on the sediment. According to Keshavars et al. (2012), finer sediment has better capability in absorbing heavy metal. Another factor affecting the high accumulation of $\mathrm{Zn}$ in mangrove sediment is because the heavy metal uptake by mangrove plant is low. According to Wen-Jiao et al. (1997), annual accumulation rate of $\mathrm{Zn}$ in Rhizophora stylosa was $0.11 \mathrm{mg} / \mathrm{kg}$. Since $\mathrm{Zn}$ is essential material for vegetation, accumulation of $\mathrm{Zn}$ in mangrove organs would not harm the growth of mangrove (Shanmugaarasu et al., 2013).

Mangrove structure plays important role in heavy metal accumulaton. Increasing discharge from anthropogenic and industrial lead to the accumulation of heavy metal contamination in mangrove sediment. Another factors affecting the accumulation of heavy metal and mangrove sediment are rock weathering, soil erosion and dissolution of salts. Low grain size as well as silt and clay fractions attributed to high specific area, favour adsorption processes of heavy metal (Goutam and Ramanathan, 2013). This condition suits the sediments of mangrove ecosystem.

\section{IV.CONCLUSION}

Mangrove ecosystem of Demak coastal area consist of 3 mangrove species including Avicennia marina Rhizophora mucronata and Rhizophora stylosa. Among 3 mangrove 
species, distribution of Avicennia marina was prevalent at all sampling stations, while Rhizophora mucronata was only found in station 3 and 4. Rhizophora stylosa was rarely found, which was only at station 4 . The concentration of $\mathrm{Zn}$ in sediment nor in the water had exceeded the maximum allowable concentration, which means that mangrove ecosystem in Demak coastal area was polluted with Zn.

\section{REFERENCES}

Chaiyara, R., M. Ngoendee and M. Krautrachue. 2013. Accumulation of Cd, $\mathrm{Cu}, \mathrm{Pb}$ and $\mathrm{Zn}$ in Water, Sediments, and Mangrove Crabs (Sesarma mederi) in the Upper Gulf of Thailand. Science Asia 39: 376 - 383. doi: 10.2306/scienceasia1513-1874.2013.39.376

Defew, L.H., J.M. Mair and H.M. Guzman. 2005. An Assessment of Metal Contamination in Mangrove Sediments and Leaves from Punta Mala Bay, Pacific Panama. Marine Pollution Bulletin 50: 547 - 552. doi:10.1016/j.marpolbul.2004.11.047

Goutam, K. And A.L. Ramanathan. 2013. Geochemical Assessment of Heavy Metal Contamination in Mangrove Ecosystem: A Brief Overview. International Research Journal of Environment Sciences 2(3): 62 - 66.

Govind, P. and S. Madhuri. 2014. Heavy Metals Causing Toxicity in Animals and Fishes. Research Journal of Animal, Veterinary and Fishery Sciences 2(2): $17-23$.

Harris, R.R. and M.C.F. Santos. 2000. Heavy Metal Contamination and Physiological Variability in the Brazilian Mangrove Crabs, Ucides cordatus and Callinectes danoe (Crustacea: Decapoda). Marine Biology 137: $691-703$

Hobbelen, P.H.F., J.E. Koolhaas and C.A.M. van Gestel. 2006. Bioaccumulation of Heavy Metals in the Earthworms Lumbricus rubellus and Aporrectodea caliginosa in Relation to Total and Available Metal Concentration in Field Soils. Environmental Pollution 144: 639 - 646. doi:10.1016/j.envpol.2006.01.019

Jakimska, A., P. Konieczka, K. Skora and J. Namiesnik. 2011. Bioaccumulation of Metals in Tissues of Marine Animals, Part I: the Role and Impact of Heavy Metals on Organisms. Pol. J. Environ. Stud. 20(5): $1117-1125$

Kamaruzzaman, B.Y., M.C. Ong and S.Z. Rina. 2010. Concentration of Zn, $\mathrm{Cu}$ and $\mathrm{Pb}$ in Some Selected Marine Fishes of Pahang Coastal Waters, Malaysia. American Journal of Applied Sciences 7(3): 309 - 314.

Kathiresan, K. 2003. How Do Mangrove Forests Induce Sedimentation? Rev. Biol. Trop. 51(2): $355-360$.

Keshavars, M., D. Mohammadikia, F. Gharibpour and A.-R. Dabbagh. 2012. Accumulation of Heavy Metals $(\mathrm{Pb}, \mathrm{Cd}, \mathrm{V})$ in Sediment, Roots and Leaves of Mangrove Species in Sirik Creek Along the Sea Coasts of Oman, Iran. J. Life Sci. Biomed. 2(3): 88 - 91.

Kishe, M.A. and J.F. Machiwa. 2003. Distribution of Heavy Metals in Sediments of Mwanza Gulf of Lake Victoria, Tanzania. Environment International 28: $619-625$.
Kumar, J.I.N., H. Soni, R.N. Kumar and I. Bhat. 2008. Biomonitoring of Trace Elements in Some Selected Aquatic Macrophytes with Reference to Lake Contamination: Aca Study of Pariyej Community Reserve, Gujarat, India. Asian J. Microbiol. Biotechnology and Environ. Sci. 10(4): $803-810$.

Kumar, J.I.N., P.R. Sajish, R.N. Kumar, B. George and S. Viyol. 2010. An Assessment of the Acumulation Potential of Lead $(\mathrm{Pb})$, Zinc $(\mathrm{Zn})$ and Cadmium (Cd) by Avicennia marina (Forssk.) Vierh. in Vamleshwar Mangroves Near Narmada Estuary, West Coast of Gujarat, India. World Journal of Fish and Marine Sciences 2(5): 450 - 454.

Lestari and F. Budiyanto. 2013. Konsentrasi $\mathrm{Hg}, \mathrm{Cd}, \mathrm{Cu}, \mathrm{Pb}$ dan $\mathrm{Zn}$ dalam Sedimen di Perairan Gresik. Jurnal Ilmu Teknologi Kelautan Tropis 5(1): $182-191$.

Maslennikova, S., N. Larina and S. Larin. 2012. The Effect of Sediment Grain Size on Heavy Metal Content. Lakes, Reservoirs and Ponds 6(1): $43-54$.

Nasr, S.M., M.A. Okbah and S.M. Kasem. 2006. Environmental Assessment of Heaby Metal Pollution in Bottom Sediments of Aden Port, Yemen. International Journal of Ocean and Oceanography 1(1): 99 - 109.

Preda, M. and M.E. Cox. 2002. Trace Metal Occurrence and Distribution in Sediments and Mangroves, Pumicestone Region, Southeast Queensland, Australia. Environment International 28: 433 - 449.

Prica, M., B. Dalmacija, S. Roncevic, D. Krcmar and M. Becelic. 2007. A Coparison of Sediment Quality Results with Acid Volatile Sulfide (AVS) and Simultaneously Extracted Metals (SEM) Ratio in Vojvodina (Serbia) Sediments. Science of the Total Environ. 389: 235 - 244.

Saeed, S.M. and I.M. Shaker. 2008. Assessment of Heavy Metals Pollution in Water and Sediments and Their Effect on Oreochromis niloticus in the Northern Delta Lakes, Egypt. 8th International Symposium on Tilapia in Aquaculture 2008: 475 - 490.

Shanmugaarasu, V., K. Saravanakumar and K. Kathiresan. 2013. Studies on Heavy Metal Accumulation in Mangrove Sediments of Northern Karnataka. Journal of Biotechnological Sciences 1(2): 146 - 152.

United States Environmental Protection Agency (USEPA). 1986. Quality Criteria for Water. EPA 440/5-86-001. May 1986. Office of Water Regulations and Standards. Washington DC., USA.

Wahyuni, H., S.B. Sasongko and D.P. Sasongko. 2013. Kandungan Logam Berat pada Air, Sedimen dan Plankton di Daerah Penambangan Masyarakat Desa Batu Belubang Kabupaten Bangka Tengah. Prosiding Seminar Nasional Pengelolaan Sumberdaya Alam dan Lingkungan 2013: $489-494$.

Wen-Jiao, Z. C. Xiao-yong and L. Peng. 1997. Accumulation and Biological Cycling of Heavy Metal Elements in Rhizophora stylosa Mangroves in Yingluo Bay, China. Marine Ecology Progress Series 159: 293 - 301.

Yunus, K., N.M. Yusuf, N.A.M. Shazili, O.M. Chuan, S. Saad, A.J.K Chowdury and J. Bidai. 2011. Heavy Metal Concentration in the Surface Sediment of Tanjung Lumpur Mangrove Forest, Kuantan, Malaysia. Sains Malaysiana 40(2): 89 - 92. 